\title{
"Surfing the Tube" for Latin American Song: The Blessings (and Curses) of YouTube
}

This article describes YouTube's functional horizons by taking note of three communicative modalities, each defined by the role that YouTube plays in disseminating expressive culture. I argue that YouTube productions are multifaceted objects composed of multiple semiotic surfaces, each with its own sensory channel and sense-making potential, operating independently of one another yet integrated into a composite communicative module.

Keywords

AfS ethnographic thesaurus: Performance, media, semiotics, corrido, hip-hop

Surfing connotes moving from place to place by gliding over the surface of things.

-Elliott Oring (2011:115)

A cross-section of YouTube reveals that it is planar in structure, and, like comic books or American cities, cellular in composition.

-John David Ebert (2011:41)

LIKE ELLIOTT ORING AND JOHN DAVID EBERT, when I strive to envision YouTube (or the Internet, for that matter) in its totality, I come up with an image of horizontal planes, surfaces, receding into an indistinct distance. Consequently, this discussion will feature horizons and surfaces as it attempts to tease out YouTube's significance for students of expressive culture. This geometry, with its planar surfaces and cellular clusters, favors extension over depth and connectivity over fidelity, and these attributes establish the parameters of the YouTube experience. That experience, in the end a human encounter with humanity's possibilities, is the ultimate target of the present essay into this realm of computer-mediated communication.

Purchased by Google in 2006, YouTube's marketing tagline is "Broadcast yourself," and millions of people worldwide have taken up this invitation since the emergence of this video-sharing facility in 2005. I have chosen to approach YouTube from the customary distance of a person scanning its surfaces for familiar material; and I

JoHn H. MCDowell is Professor and Chair in the Department of Folklore and Ethnomusicology at Indiana University, where he edits the Journal of Folklore Research Reviews

Journal of American Folklore 128(509):260-272

Copyright ( 2015 by the Board of Trustees of the University of Illinois 
frame this meditation in terms of blessings and curses because, as I see it, YouTube, like all technologies, simultaneously delivers and retracts, reveals and conceals. This technology has different kinds of users; my comments here are directed primarily toward one slice of this massive public: students and scholars of expressive culture who approach YouTube for examples of performed culture. The downside to this medium, especially acute for these users, is obvious. Prominently, it presents a thin facade that lacks the experiential depth afforded by our customary ethnographic procedures. A second concern for those who surf the tube in search of situated performances is the disorganized character of the YouTube holdings, a direct result of YouTube's primary attraction, its open and egalitarian qualities. The unsorted status of the materials, in combination with the lack of careful contextualization, makes YouTube a sometimes frustrating, and often a perilous, experience. A third issue with YouTube, one that impacts all users, is an indifference to perceptual quality that is endemic to much online communication.

But my purpose here is not to dwell on the downside of YouTube, but rather to embrace it as a pervasive phenomenon of our time with conspicuous enticements for folklorists. This initial foray will explore two basic questions, one concerned with YouTube's ontology, the other, with its epistemology. In reference to ontology, we will want to know, What kind of object in the world is YouTube? I will approach this question by asking, How does YouTube operate in the world? In addressing this facet of our topic, I will point to YouTube's functional horizons by taking note of three communicative modalities, each defined by the role that YouTube plays in disseminating expressive culture. In Modality A, let's call it the archival modality, YouTube serves to collect content that exists independently of its own matrices. Modality B, which we might refer to as the interdependent modality, features a tight symbiosis between YouTube and the circulation of expressive culture. Finally, in Modality C, the YouTube-native modality, content is created explicitly for YouTube dissemination.

With regard to epistemology, I will draw attention to the semiotic surfaces, or loci of semiosis, that are activated in YouTube productions, and assess the sorts of information we might expect to obtain from each of them. I argue that YouTube productions are multifaceted objects composed of multiple semiotic surfaces, each with its own sensory channel and sense-making potential, operating independently of one another yet integrated at some level into a composite communicative module. ${ }^{1}$ These meaning-making surfaces, as we shall see, are of two kinds: one set is tied to performance features of the expressive culture represented in the YouTube video; another is tied to contextual factors pointing to senders and receivers of YouTube videos. In order to gain a handle on the ontology and epistemology of YouTube, I will draw on content areas where YouTube has become a resource for my research, and I will make use of exemplary YouTube videos from these settings in assessing YouTube's folkloristic valences. The first of these, to be addressed in relation to YouTube ontology, is the Mexican heroic song tradition known as the corrido, including its significant contemporary manifestation, the narcocorrido; the second, to be sampled in discussing YouTube epistemology, is a Quichua hip-hop production that originates with a group of young indigenous musicians from the area around Otavalo, Ecuador. 


\section{YouTube Ontology}

It might seem that YouTube is strictly another medium for conveying folklore into a derivative or secondary environment, much as the printed word takes oral recitation into a literary zone, the photograph captures an image of the crafted object, and recording technology takes live music into fixed and permanent storage devices. Without a doubt, YouTube continues this time-honored trend, and I'd wager that folklore performances of any conceivable sort, in all imaginable genres and venues, can be found archived on YouTube. Let's explore, briefly, YouTube's function in Modality A as an archive of performances in vernacular expressive genres.

YouTube can be seen as a comprehensive institutional archive of vernacular artistic performance, documented in live performance as well as in mediated products such as phonograph records, magnetic and cassette tapes, CDs, and DVDs. Videos documenting live performance come in various degrees of formality, ranging from raw footage of apparently spontaneous performance to polished footage of professional artists at work on major stages. Production values also range from the rudimentary to the slick. Expressive culture performances previously captured on recording devices and now relocated to YouTube are often difficult to access in their original castings, so YouTube in its archival capacity performs a truly valuable service.

As an example of this service rendered by YouTube, I can reference my ongoing work with the ballad inventory I gathered during more than a quarter-century of field investigation on Mexico's Costa Chica, a slip of land along the southwestern Pacific Coast where the states of Guerrero and Oaxaca meet. In preparing my new anthology of corridos from Mexico's western coast (McDowell 2015), I ran checks on YouTube for the songs in my Costa Chica collection and was pleasantly surprised to find that a good many of these local ballads can be accessed there-at current count, more than 30 of them, many of these available in multiple versions. The great majority of these performances are digitized and then uploaded from records, tapes, or CDs that were produced on the Costa Chica and marketed locally. These recordings feature, for the most part, musicians who are from Guerrero's coasts and are deeply familiar with the regional ballad tradition. There are, as well, a number of live performances of these songs, mostly in informal settings, that have been recorded and uploaded to YouTube.

I have found it useful to compare YouTube versions with the performed versions I documented in the field. A case in point is "Pedro el Chicharrón," a standard in the Costa Chica repertoire that I have recorded over the years in multiple versions. YouTube offers yet another version of this corrido, about a notable tough guy who meets a violent death, at this site: $h$ ttp://www.youtube.com/watch? $=2$ wms 9 Uwl5ms (accessed on May 21, 2013). This performance is taken from a locally circulating 33 rpm record released by Los Donnys de Guerrero. This version of the ballad is especially interesting for me, as it contains a stanza conveying the protagonist's full name, Pedro Baltazar, not present in the versions I have collected.

If, in Modality A, YouTube can be characterized as an archive of expressive culture, it is, we must hasten to observe, an unusual archive that makes special demands on those who would use it. The very features that we would construe as the virtues of the Internet in general (and of YouTube in particular), the fact that it is an open, 
unregulated, and unsorted medium, create dangers for the unwary. YouTube as archive has no signposts, no quality indicators - so it's viewer beware. The more previous exposure a person has to the expressive genre and its source community, the better the chances for making good YouTube choices. This detail makes YouTube excursions risky, especially for the uninitiated among our students, and we need to develop protocols for effective navigation of this medium. The first principle in such protocols, it seems to me, is this: learn as much as possible about your target before venturing onto YouTube for examples. The second principle here might well be this: once you have selected a YouTube video, make every effort to figure out precisely what you are dealing with by scouring the item's many semiotic surfaces for all shreds of pertinent information.

Turning now to Modality B, the interdependence of YouTube and expressive culture, I offer a YouTube video featuring the late, great Jenni Rivera, singer-songwriter, television personality, and media figure, and wildly successful entrepreneur based in Encino, California. Until her untimely death on December 9, 2012, Jenni was a human dynamo at the center of a financial empire built initially on musical performances but extending outward into cosmetics, reality TV, and the movies. A piece of this economic juggernaut is the recourse to YouTube as a venue for promoting Jenni as "La Misma Gran Señora" (That Same Fine Lady), and in her persona as "La Diva de la Banda" (The Diva of Banda Music).

I take us to a YouTube video documenting Jenni's performance of "La Chacalosa" (The Bad-Ass Girl), a narcocorrido, that is, a ballad featuring exploits in the crossborder drug business. Narcocorridos abound on YouTube, but this one features an unexpected twist: in this male-oriented genre, it is a woman who is celebrated here. This ballad's opening stanzas are indicative of its theme: ${ }^{2}$

Me buscan por chacalosa
soy hija de un traficante,
conozco bien las movidas
me crié entre la mafia grande
de la mejor mercancía
me enseñó a vender mi padre.
Cuando cumplí los quince años
no me hicieron quinceañera,
me heredaron un negocio
que buen billete me diera,
celular y tambien beeper
para que todo atendiera.

Me buscan por chacalosa

soy hija de un traficante, me crié entre la mafia grande de la mejor mercancía me enseñó a vender mi padre.

Cuando cumplí los quince años no me hicieron quinceañera, me heredaron un negocio que buen billete me diera, para que todo atendiera.

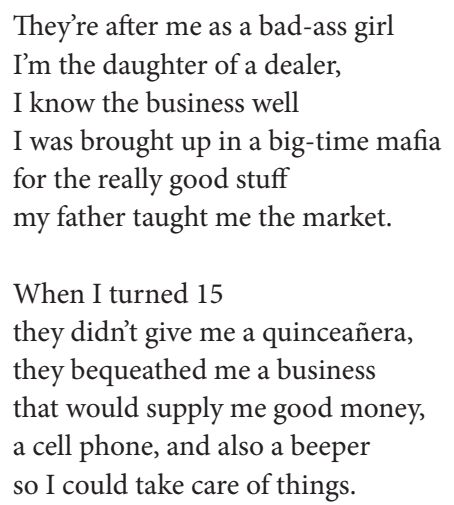

The performance in question took place in the Nokia Theater in Los Angeles in 2010 in front of a large and enthusiastic crowd, and I accessed the YouTube video under examination here on May 21, 2013, at http://www.youtube.com/watch?v=NrPpjtHdKZw. Attesting to YouTube's ubiquity and variety, there are, as well, plenty of more amateur videos of this song on YouTube. The immediate and lasting impression is that the video under consideration here contrives to present Jenni as a celebrity figure. The scene is set by a stirring announcement of her name on the venue's ample sound 
system and a striking visual of her name, JENNI RIVERA, in rotating blocks with the letters gilded in golden hues and glistening with sparkles of light. Roman fountains spout their flares as she intones and holds the syllables of the corrido's first line in her powerful, deep-throated voice.

Following this a cappella opening, the band starts playing as Jenni completes the lines of the first stanza and continues through the song's remaining stanzas. It is evident that five or six cameras are active in filming this performance, as our point of visual encounter moves seamlessly from frontal views to side views to views from behind the singer, out into her adoring audience. This is a sophisticated video production that successfully portrays Jenni Rivera as a diva, a celebrity, and perhaps, a goddess. The YouTube video of this performance of "La Chacalosa" at the Nokia Theater must be understood as a core piece in a larger construct, the apotheosis of Jenni Rivera. Jenni's performance at the Nokia Center was a free-standing event, yet this YouTube product operates as a component in this bigger picture; the offline event and the online representation on YouTube are inextricably linked. ${ }^{3}$

Anthony Buccitelli, writing in Trevor Blank's useful compilation of articles, cautions that "folklorists must stop thinking of digital technologies as simply media that record or transmit offline folklore. Instead, we must think of them as places of performance" (2011:73; emphasis in original). Modalities B and C, the interdependence and YouTube-native horizons, envision the increasing centrality of YouTube as a medium for the origination of expressive culture performances. In Modality C, this drift reaches completion, since these videos are constructed as YouTube artifacts. In this modality, YouTube is the performance venue of record, the intended and natural channel for folkloric communication. This modality extends YouTube's ontology from a reflective to a generative posture, from reproduction to production, and bestows upon this medium an enhanced operational role in the world. It reminds us of a fundamental principle concerning the interaction of humans and machines: that, in Charlie Gere's words, "our technologies are always in the process of changing us" (2008:8). If YouTube provides the means of projecting extant human culture onto the multiple, dispersed screens of the world's computers, it also affords a venue for channeling human imaginations and energies into new productivity conditioned by its unique distributive and perceptual features.

In Modality C, the YouTube-native functional horizon, expressive culture performances are embedded in productions that take advantage of the medium's inherent properties. It turns out that the short video clip, engineered to weave visual, sonic, and textual surfaces into an effective communicative product, is an artistic form with expansive possibilities. Modality C offers mini-documentaries, how-to videos, and significantly, videos that we can embrace as a form of vernacular expression in their own right - that is, videos as and not of vernacular expression. ${ }^{4}$ With such a variety of intentions on display in this medium, we must pay close attention to the mission of YouTube videos as they traverse the gap between senders and receivers.

One particularly striking mission can be traced in the realm of the narcocorrido. There is a big audience for narcocorrido performances, and, as noted, narcocorridos are prominently featured in YouTube's archive of vernacular performance. But in addition to this general audience, a more specific narcocorrido mission is reported 
in news outlets. Ballads are being placed on YouTube as pieces in a signaling system that link a diverse set of protagonists-members of the drug cartels; their rivals in other cartels; the police, army, and other enforcement agents; and an enthusiastic fan base that consumes the songs and adopts, in varying degrees, the signs and symbols of the drug world. What happens, according to news accounts and testimonies from active players in these settings, is that narcocorridos are commissioned and created as music video collages explicitly for uploading on YouTube, with the purpose of sending a message to a specific audience. ${ }^{5}$

A reporter with the Washington Post Foreign Service, Manuel Roig-Franzia, wrote in the Washington Post about this phenomenon. His piece, titled "Mexican Drug Cartels Leave a Bloody Trail on YouTube," points to several instances where authorities believe narcocorridos posted on YouTube were used for "transmitting threats, recruiting members and glorifying the narco-trafficker lifestyle of big money, big guns and big thrills" (Roig-Franzia 2007). Recently I came across a YouTube narcocorrido that had the markings of a cartel statement, titled "Corrido de Acapulco" or alternatively, "La Toma de Plaza" (Taking the Plaza). This corrido was uploaded in June of 2010, in the wake of a ferocious half-year of brutal and sometimes theatrical violence in the area around Acapulco in southern Mexico. As it happens, the reigning master of Acapulco’s plaza, meaning its lucrative drug routes, Arturo Beltrán Leyva, had been killed by Mexican marines in Cuernavaca in January of 2010, precipitating a vicious struggle for succession to this position. "La Toma de Plaza" emerges in this context and appears to announce a resolution to the contest.

The words to this corrido are suggestive of in-group communication embedded in a philosophical assessment of life's ups and downs. The first two stanzas convey this flavor: 6

\begin{tabular}{|c|c|}
\hline $\begin{array}{l}\text { "Muerto el rey, viva el rey," } \\
\text { así comienza el corrido, } \\
\text { en el puerto de Acapulco } \\
\text { algo grande ha sucedido, } \\
\text { cambiaron mucho las cosas } \\
\text { todos saben el motivo. }\end{array}$ & $\begin{array}{l}\text { "The king is dead, long live the king,' } \\
\text { that's how the corrido begins, } \\
\text { in the port city of Acapulco } \\
\text { something big has gone down, } \\
\text { things really got changed around } \\
\text { everyone knows the reason. }\end{array}$ \\
\hline $\begin{array}{l}\text { Cambió de jefe la casa } \\
\text { pero la línea es la misma, } \\
\text { unas veces muy abajo } \\
\text { otras veces muy arriba, } \\
\text { este mundo es muy pequeño } \\
\text { así da vueltas la vida. }\end{array}$ & $\begin{array}{l}\text { The boss of the house was replaced } \\
\text { but the line is still the same, } \\
\text { at times, things are way down } \\
\text { at other times way up, } \\
\text { this world is a very small place } \\
\text { that's how life spins about. }\end{array}$ \\
\hline
\end{tabular}

It is interesting that as of November 2012, this corrido could no longer be accessed on YouTube, an indication, perhaps, that it was entangled in the hostilities that brought so much trouble to Acapulco in this period. In this manifestation, YouTube corridos become active elements in a deliberate yet veiled communicative network. Here, the corrido takes on a central role in negotiating relationships in this web of interacting players, and YouTube functions as the channel of choice for the conveyance of pointed messages. 


\section{YouTube Epistemology}

We turn now to questions of epistemology, inquiring, What can we know about YouTube productions? A proper accounting of YouTube's expressive capacity requires close attention to each of its semiotic surfaces as well as a diagnosis of how these surfaces interact to compose the integrated whole. So, what are these interlocking loci of semiosis? I propose that we identify two different kinds of semiotic surfaces in YouTube products: those tied to performance features and those tied to contextual features. In the category of performance features, we need to recognize visual images, acoustic signals, and textual elements. In the category of contextual features, I'd make mention of two core components: information tied to the act of uploading, and information tied to viewer responses. In the former category, we encounter these elements: video titles, uploader names and handles, and contact information; uploading dates; and explanatory blurbs provided by the uploader. In the category of viewer response, we find elements such as the number of views and the number of thumbs up or thumbs down, as well as the thread of commentary supplied by viewers, when such comments are present.

Let's explore the harvest folklorists might anticipate in this medium by attending closely to a YouTube clip from the Quichua-speaking Runa of the Otavalo region in highland Ecuador. In my work with this community, I have been asking a series of questions about the crafting of indigenous identity in this highly visible, highly mobile, and increasingly cosmopolitan community. I am particularly interested in the interface between what might be thought of as internal, private, and organic expressions of cultural or ethnic identity, and those identity formulations directed to external audiences such as the multitudes of tourists who visit Otavalo with its famous indigenous market, and the many people, all across the globe, who experience Quichua Runa culture thanks to the wandering merchants and musicians from the Otavalo area who find their way to these near and distant places.

Early in this research, I identified the commercial compact disc as a significant artifact of identity production (McDowell 2010). But my target here is YouTube, and I want to explore in some depth a YouTube video clip that offers an abundance of valuable evidence. I refer to a music video titled "Identidad" (Identity), a production by a new generation of Otavalo Runa musicians, Los Nin Katary (accessed on May 21, 2013, at http://www.youtube.com/watch?v=7yLXfruOQAs).

In this production, the members of this group weave together the old and the new into a powerful evocation of the Otavalo Runa experience in their Imbabura homeland. The musical idiom is hip-hop, modeled on North American prototypes, but this idiom gradually expands to encompass or perhaps transform into traditional forms associated with Otavalo Runa Inti Raymi festival celebrations. ${ }^{7}$ Indeed, the youth group interacts throughout the video with an established group of musician elders, Grupo Sisay, to create a musical dialogue placing the new in contact with the old, and eventually, integrating the two.

There is no time here to even begin to excavate the cultural wealth of this YouTube production, but let me point, in a preliminary fashion, to a few sites of potential analysis in keeping with folkloristic priorities. Starting with the performance features made available in this production, we can note that the visual and sonic palettes are rich; 
on the visual surface, we witness a sequence of images and actions focused mainly on two contrasting axes, the youthful hip-hop performers and a group of mature musicians, with intervening shots evocative of the natural and cultural setting of the Otavalo Runa community. Music is centered here as the main attraction, and the two styles represented in this YouTube production would seem to be miles apart, though the initial, persistent rhythmic arpeggios on a plucked string instrument are compatible with the hip-hop rhythms that dominate the first segment of the video. In the video's second segment, the hip-hop sound begins to recede into the background as the traditional flutes of Grupo Sisay take center stage. Finally, in the video's closing segment, the two sounds blend into a rhythmic and melodic unison, and we experience a remarkable conjunction of these two musical voices. This sonic convergence hints at the fundamental ethnic continuity across the generations, as the youthful Los Nin Katary musicians and the older Grupo Sisay musicians come into synchrony on the assertive stomping beat of the Inti Raymi festival sound, and the footsteps of the dancing youngsters seem to merge with the footsteps of their elders.

An inventory of the visual imagery produces a catalogue of Otavalo Runa identity markers-food, festival, music, dance, women's work, traditional agriculture and pastoralism, and so forth. But I want to touch briefly on the spoken, or chanted, word in this YouTube video. Even on first viewing, you perceive that it is structured into three segments, the first marked by its Spanish-language lyrics, the second by a shift to the Quichua language, and the third, a kind of coda, moving beyond text to effect the union of the generations. The vocals in the first segment assert a reverence for ethnic tradition, and address this theme through a key concern for indigenous youth: the decision of young men to maintain their hair uncut so it can be woven into the distinctive single braid that is characteristic in the traditional indigenous community. The performers here declare their loyalty to this custom, and punch back at other, more acculturated youth, who condemn those who wear the braid. This loyalty to custom is portrayed as emblematic of a political position that values the traditions of the community, especially its rich panorama of music and dance forms. This fealty to custom is phrased, in this Spanish portion, as follows:

$\begin{array}{ll}\text { eso es lo que significa } & \text { this is what it means } \\ \text { ser un verdadero Runa } & \text { to be a true Runa } \\ \text { representando } & \text { representing } \\ \text { desde la cuna } & \text { from the cradle } \\ \text { la cultura pura. } & \text { the pure culture. }\end{array}$

The second segment pursues this commitment to traditional values and draws upon a trope of ethnic citizenship, where following in the footsteps of the ancestors and cleaving to Runa values are presented as the pathway to sumak kausay, the good and proper life. Here is a sample of this Quichua discourse:

Nangunapi purishpa Runa kausaita yachani.

I know how to walk the fine path of the exemplary Runa life.

Tukuilla huambrakuna jatarishun ñukanchik kausaimanta.

All the youth will lift up our way of life. 
Runa kausaita jahuaman apangapak,

In order to carry forward the Runa way of life,

Ama kungashpa

Not forgetting,

Ama chingashpa

Not getting lost,

Ama shitashpa.

Not setting things aside.

The three-part command at the end of this excerpt is a clever play upon the traditional Incan counsel, known today all across the Quechua-speaking world: ${ }^{8}$

\author{
Ama killay \\ Don't be lazy, \\ Ama llullay \\ Don't lie, \\ Ama sisay \\ Don't steal.
}

For all the alignment with tradition in this video, it is important to note that the youthful musicians remain physically apart from the festive scenes depicted in it; they move in step with the Inti Raymi beat, but their dance is done on a hillside overlooking the town. This YouTube video expresses solidarity with the community even as it portrays some level of separation from it. Los Nin Katary seem to be saying that they value their ethnic culture and will participate in it, but on their own terms and in their own way. The interplay of visual, sonic, and textual surfaces conveys a deep reverence for community in combination with a commitment to "keeping it real" as an artifact of youthful independence. ${ }^{9}$

This video, native to YouTube, is, in itself, a crafting of identity, speaking both within the community, as an exhortation to conserve native values and customs, and outside the community, as a vivid presentation of Otavalo Runa ethnic identity. It amounts to a folklorist's bonanza, a crafting of identity engineered by Otavalo youth seeking to define their place in their natal community even as they acknowledge the pull of national and international models. The performance features of "Identidad" weave a multilayered and profoundly evocative rendition of the contemporary Otavalo experience. The performative semiotic surfaces that YouTube makes available are richly developed and exploited to create a powerful manifestation of modern indigeneity. This YouTube production draws upon existing performance routines but weaves them together into a unique communicative vessel, a tight package extending under four minutes in elapsed time but concentrating visual, sonic, and textual elements for maximal impact. It creates the opportunity for consumption of a complex message about young people confronting and resolving cultural challenges.

The contextual features for YouTube videos convey information provided in the uploading process and responses contributed by the viewers. Uploader names are revealing of public identities, and, when self-designated handles are used, of aspirational identities as well. The viewer-response surface serves as a referendum, tallying 
viewer interest and approval, and as a forum, collecting viewer reactions. In Los Nin Katary's "Identidad," the uploader details, as is not unusual on YouTube, are minimal. We learn that the uploader is Curi Cachimuel, who had at that time uploaded 42 videos, and that the uploading happened on March 9, 2009. Some uploaders make an effort to frame the uploaded video and state their motives for placing it on YouTube, but there is no such commentary here. The search cues for this Web address, however, do help us locate Curi Cachimuel via his MySpace page, where we learn that he is a musician (a drummer) as well as a musical arranger and promoter, and that he is a member of a well-regarded Otavalo musical group, Yarina, established in Boston, Massachusetts. Curi Cachimuel's MySpace page offers some clues as to his stance in these matters, avowing an obligation to both preserve and disseminate Otavalo Runa traditions (http://www.myspace.com/intikuri; accessed May 21, 2013). ${ }^{10}$

If the uploader's surface is sparse here, the same cannot be said of the viewerresponse surface. There are the usual statistical pieces: as of May 21, 2013, there had been 145,036 visits to this site, and it had received 391 thumbs up to 18 thumbs down. The real action is in the thread of viewer comments, totaling, as of this writing, 316 contributions. Here, as in the expansion of YouTube into a generative medium, we have a value-added product, a welcome derivative of this particular medium's innate potentialities. Sorting through these commentaries, one discovers a remarkable forum of popular opinion, with contributions framed in a range of discursive styles, including a highly customized writing variety that appears to be the creature of online communication. Two themes are predominant in this commentary: one, a congratulatory salutation of the performers' accomplishment, the other, a rude mockery of their project.

Interestingly, many of the salutes are grounded in specific geographical locations, most of them coming in from various parts of the Spanish-speaking world, bespeaking a strong pan-Latin American cultural solidarity. Beyond these expressions of hemispheric solidarity, the comments evince a heated debate about the merits of Los Nin Katary's project. There are both derisive and congratulatory messages in this thread, but this one, reproduced verbatim from the site, captures the general drift of the comments:

comment by “theosaso," May 2012:

Hablas q los indigenas han perdido identidad y tu primero te vez usando pantalones que parece se los has robado a un gringo con tres metros de basta, camisetas que parecen maternales ... vamos amigo, hablame serio, muy original tu propuesta y tu música, un artista con sentido ... me parece excelente el mensaje que intentas transmitir, pero el cambio empieza por uno mismo ... saludos.

(You say that the indigenous have lost identity and you first appear wearing pants that seem to have been stolen from a gringo with three meters of girth, shirts that seem to be for pregnant women ... come on, my friend, talk in earnest with me, your proposal and music, very original, an artist with feeling... the message you are trying to transmit seems excellent to me, but change begins with one's self first ... greetings.) 
There are many more themes in play in this commentary thread, which could be mined for potentially any number of concerns, relating to the contents of the video itself and shifting outward from that base to the viewer population's modes of thought and expression. YouTube videos tend to trigger these commentary threads, and this semiotic surface makes YouTube an invaluable forum of popular opinion as well as, as we have seen, a precious archive of vernacular artistic performance. ${ }^{11}$

\section{Conclusion}

It is my hope that this discussion of YouTube's essential properties will help guide us as we continue to explore this medium as a folkloristic resource. Let me close by pointing to what I see as aspects of YouTube ontology and epistemology worthy of further exploration. Regarding ontological considerations, we will want to come to a clearer understanding of both the reflective and generative capacities of this medium. Our brief excursion into the world of corridos illustrates YouTube's multiple functional horizons-as a repository of corrido performance, as an adjunct to corrido performance, and, in the case of some narcocorridos, as a medium for corrido performance. A number of questions arise in contemplating YouTube's functional horizons: If YouTube is an archive of expressive culture, just what kind of archive is it, and what procedures will enable us to make the best use of it? We will want to know more about how YouTube impacts the production and circulation of expressive culture, and we will have to absorb the implications of the idea that some YouTube videos are, in themselves, vernacular art objects, just as, as Robert Glenn Howard (2005) argues, some websites are properly viewed as vernacular productions.

With regard to epistemology, there is much to know about YouTube's semiotic surfaces. Our consideration of Los Nin Katari's "Identidad" has barely scratched the surface of the informational resources made available in this YouTube production. In pursuing these features in greater depth, we can inquire, for performance features, how visual, sonic, and textual components interact, as well as where these performances originate and how they are processed and combined in YouTube productions. As for YouTube's contextual features, we are likely to dwell on the commentary threads, since there is valuable information lodged in both the style and the content of these contributions.

One take-away from this meditation on YouTube is the need for supplementary offline and online ethnographic research. For each of the YouTube videos discussed in this essay, questions of an empirical nature linger to prompt further discovery. How are these uploaders connected to the performers and performances they have chosen to put on display? What can we learn about these uploaders' intentions and their intended audiences? These queries pose broader empirical zones where ethnographic inquiry might usefully extend our appreciation of YouTube's modalities and surfaces, by inquiring: How do people access expressive culture through YouTube? What are their habits, patterns, and pathways through the maze? And what motivates people to upload expressive culture to YouTube? How do they make their selections and process the raw materials, and whom do they expect to address with these videos? 
As grounded ethnography traces in these hidden dimensions of the YouTube phenomenon, we stand to gain a firmer grasp on YouTube's interactions with vernacular expressive culture. Folklorists address the interplay of creativity and tradition in the production of stylized performances; by recognizing YouTube as both an archive and locus of vernacular creativity, we can carry our project forward into this digital world that we now inhabit.

\section{Notes}

1. I thank Richard Bauman for spurring my thinking about the interplay of YouTube's communicative surfaces.

2. This and all subsequent transcriptions from performances in Spanish and in Quichua are my own; all the English translations in this essay are my work as well.

3. I have not yet been able to trace the exact connection between this video and the Rivera enterprises, though I am confident there is one in light of the access granted to the performance and professionalism achieved in documenting it.

4. I must thank an anonymous reader of this article for this felicitous phrase.

5. Recent postings of YouTube corridos sometimes carry the banner "Aprobado por Cartel" (Approved by the Cartel), though, as Elijah Wald cautions (personal communication), these claims, like all else in this murky world, must be taken with a grain of salt.

6. For the full text of this corrido, with an account of its visual surface as well, see McDowell (2012). I treat this corrido as a throwback to the mainstream corrido tradition, a commemorative narration in third-person voicing that tells its tale in an engaging fashion and assimilates its protagonists to a heroic worldview.

7. Inti Raymi is the Quechua term for the Incan festival of the sun, celebrated around the time of the summer equinox. In Otavalo and surrounding areas, festivities at this time used to be known as San Juan, as they are associated with the feast of Saint John (as well as that of Peter and of Paul), falling in late June. But in the 1990s, according to Lynn Meisch (2002:252), the Runa imported the term Inti Raymi from Peru to refer to their local festivities.

8. The Quechuan language family consists of varieties spoken by some 10 million people along the Andean cordillera and its eastern periphery; Quichua is the label for the Quechua spoken in Ecuador.

9. I thank Fernando Orejuela for reminding me of this imperative.

10. I have anecdotal evidence that Los Nin Katary are youthful kin of the Yarina band members, but this possibility needs to be more fully explored.

11. I note in passing another value-added contextual feature of the YouTube medium, the panels of suggested videos that appear in conjunction with downloaded videos. These suggestions can be useful. For example, from the "Identidad" screen, I was prompted to link to an interesting video documentary about the Inti Raymi festival in Chicago that year (see http://www.youtube.com/watch?v=YQjfSzPNKns; accessed May 22, 2013).

\section{References Cited}

Blank, Trevor, ed. 2011. Folk Culture in the Digital Age: The Emergent Dynamics of Human Interaction. Logan: Utah State University Press.

Buccitelli, Anthony. 2011. Performance 2.0: Observations toward a Theory of the Digital Performance of Folklore. In Folk Culture in the Digital Age: The Emergent Dynamics of Human Interaction, ed. Trevor J. Blank, pp. 60-84. Logan: Utah State University Press.

Ebert, John David. 2011. The New Media Invasion: Digital Technologies and the World They Unmake. London: McFarland \& Company.

Gere, Charlie. 2008. Digital Culture. London: Reaktion Books. 
Howard, Robert Glenn. 2005. Toward a Theory of the World Wide Web Vernacular: The Case for Pet Cloning. Journal of Folklore Research 42(3):323-60.

McDowell, John. 2010. Rethinking Folklorization in Ecuador: Multivocality in the Expressive Contact Zone. Western Folklore 69(2):181-210.

- 2012. The Ballad of Narcomexico. Journal of Folklore Research 49(3):249-74.

2015. ¡Corrido! The Living Ballad of Mexico's Western Coast. Albuquerque: University of New Mexico Press.

Meisch, Lynn. 2002. Andean Entrepreneurs: Otavalo Merchants and Musicians in the Global Arena. Austin: University of Texas Press.

Oring, Elliott. 2011. Jokes on the Internet: Listing toward Lists. In Folk Culture in the Digital Age: The Emergent Dynamics of Human Interaction, ed. Trevor J. Blank, pp. 98-118. Logan: Utah State University Press.

Roig-Franzia, Manuel. 2007. Mexican Drug Cartels Leave a Bloody Trail on YouTube. Washington Post, April 9. http://www.washingtonpost.com/wp-dyn/content/article/2007/04/08/AR2007040801005.html. 